\title{
New rail-road tractor with a combustion engine and an alternative electric drive
}

The paper presents the general concept of an innovative rail-road tractor solution. The innovation of the solution is characterized by equipping the combustion engine tractor with an additional electric drive for the wheels of the rail drive system. The options of using the tractor in operation along with rolling stock were presented. The results of preliminary conceptual work on the selection of electric propulsion and energy storage devices to power electric motors has been illustrated. Directions for further conceptual and design research were also determined. The aim of the paper is to popularize the results of the performed research work carried out at the Institute in the field of rail-road vehicle development.

Key words: rail-road tractor, combustion engine, electric drive system

\section{Introduction}

The rapid consumption of fossil fuel and increased environmental damage caused by it have given a strong impetus to the development of fuel-efficient vehicles. Hybrid electric vehicles (HEVs) have evolved from their inchoate state and are proving to be a promising solution. Not only do HEVs provide better fuel economy and lower emissions satisfying environmental legislations, but also they dampen the effect of rising fuel prices on consumers. HEVs combine the drive powers of an internal combustion engine and an electrical machine [10].

The directions of road and rail vehicle drives development aim to implement hybrid and electric drives due to their ecological and economic advantages. The state of the art in the field of energy storage devices enables the design of fully or partially electrically powered vehicles [2, 4].

Existing energy storage in the form of battery packs, e.g. lithium-ion, do not ensure satisfactory mileage of motor vehicles or operating time of electric drives and require the vehicle to be shut down in order to recharge the battery.

Robust and affordable batteries are a primary challenge for hybrid vehicles. Various HEV battery compositions have been tried in the past with the best results from lithium-ion derivatives. Battery should be able to supply high power over short periods and must be capable of enduring millions of transient shallow cycles over vehicle life. [10].

In the case of hybrid diesel-electric vehicles, continuous operation of the vehicle is possible through appropriate synchronization of the cooperation of the internal combustion engine with the electric drive system.

The conducted literature review revealed a small and lacking stock of domestic and foreign publications on the subject of rail-road vehicles with HEV drives. This article is based mainly on the experience of the designers and producers of rail-road vehicles from the Lukasiewicz Research Network - Institute of Rail Vehicles "TABOR" included in several publications. A previous study [7] presents the parameters and design features of the base tractor, which was selected for adaptation to a rail-road vehicle. The process of creating a road-rail tractor by equipping the base tractor with devices that make it possible to adapt it for track driving and shunting work with wagons was described in [8]. The simulation results of derailment safety tests [3] showed that with the minimum pressure of the rail rollers on the track (pressure in the actuators being $1.5 \mathrm{MPa}$ ), the criteria for safe travel through the standard test track curve with a radius of $150 \mathrm{~m}$ were met. In the publication [5], the Authors presented characteristics of rail-road vehicles designed at the Institute. The study [9] discussed the design features and the possibility of using a rail-road tractor for shunting works on railway tracks and other specific works on both railway and road infrastructure.

Having a well-developed rail-road vehicle and also wanting to respond to the developing trends in HEV vehicles, in Łukasiewicz - IPS "TABOR", an indirect dieselelectric drive system between the electric and hybrid drive was proposed. The main drive system is an internal combustion engine, during engine operation the energy storage systems are charged, and within a limited time defined by the capacity of energy storage, it is possible to drive solely using the electric motors. This drive concept is planned to be implemented in the C120 type rail-road tractor shown in Fig. 1 (based on the CLAAS Arion 610 diesel agricultural tractor), which is intended for shunting works on railway sidings in open areas.

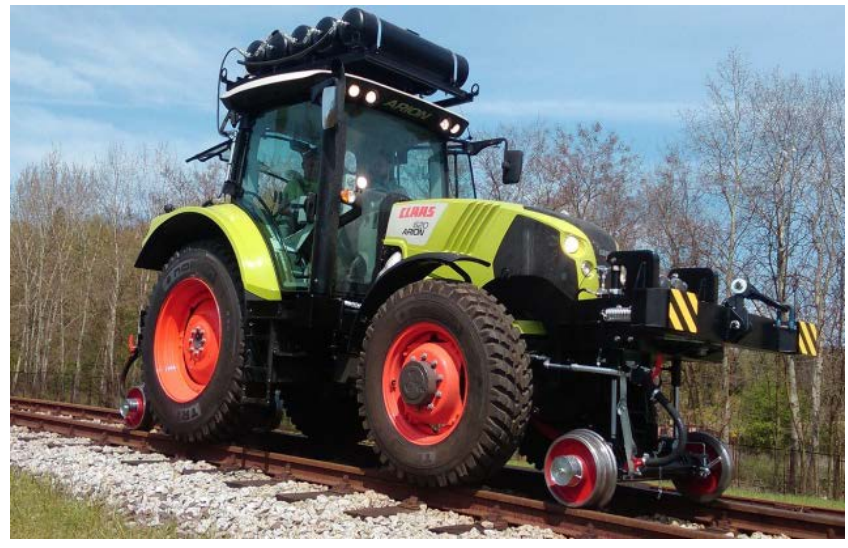

Fig. 1. Rail-road tractor design based on the CLAAS Arion 610 
A diesel-electric tractor may be used in locomotive sheds, railway depots and rolling stock repair plants. In such cases, there is a need to push the rolling stock from the open space to an enclosed inspection or repair hall, where the emission of exhaust gases becomes harmful to the staff engaged in maintenance or repair of the rolling stock.

The proposed concept of the diesel-electric drive allows the drive to be switched from combustion to electric mode before moving the rolling stock into enclosed spaces, eliminating harmful exhaust emissions.

The maximum possible tractive force of the tractor in the electric drive mode, determined by the weight of the tractor and the adhesion of the driving rollers of the rail running gear, is (theoretical/maximum force resulting from the assumed coefficient of friction and tractor weight):

$$
\mathrm{F}=\mathrm{Q} \cdot \mu=100 \mathrm{kN} \cdot 0,3=30 \mathrm{kN}
$$

where: $\mathrm{Q}$ - total pressure of the rollers of the rail running gear on the track rails, $\mu$ - maximum friction coefficient of the drive rollers against track rail heads.
With such tractive force, a set of 20 passenger wagons can be brought into the hall, e.g. at the Warsaw-Grochów rail station. To achieve the tractive force of a tractor with a value of $\sim 30 \mathrm{kN}$, it is necessary to install electric motors of appropriate power and sufficient energy storage to power them.

Based on the conducted analyzes, it can be concluded that classic slow-running asynchronous motors, due to their dimensions, can provide $\sim 20 \mathrm{~kW}$ of power, which is insufficient to generate a tractive force of $\sim 30 \mathrm{kN}$.

The conceptual work focused on increasing the energy storage capacity in order to extend the tractor operating time in electric driving mode and the use of a classic asynchronous electric motor to drive the rail axis rollers.

\section{Tractor design concept}

The tractor concept based on classic low-rpm asynchronous motors was shown in Fig. 2.

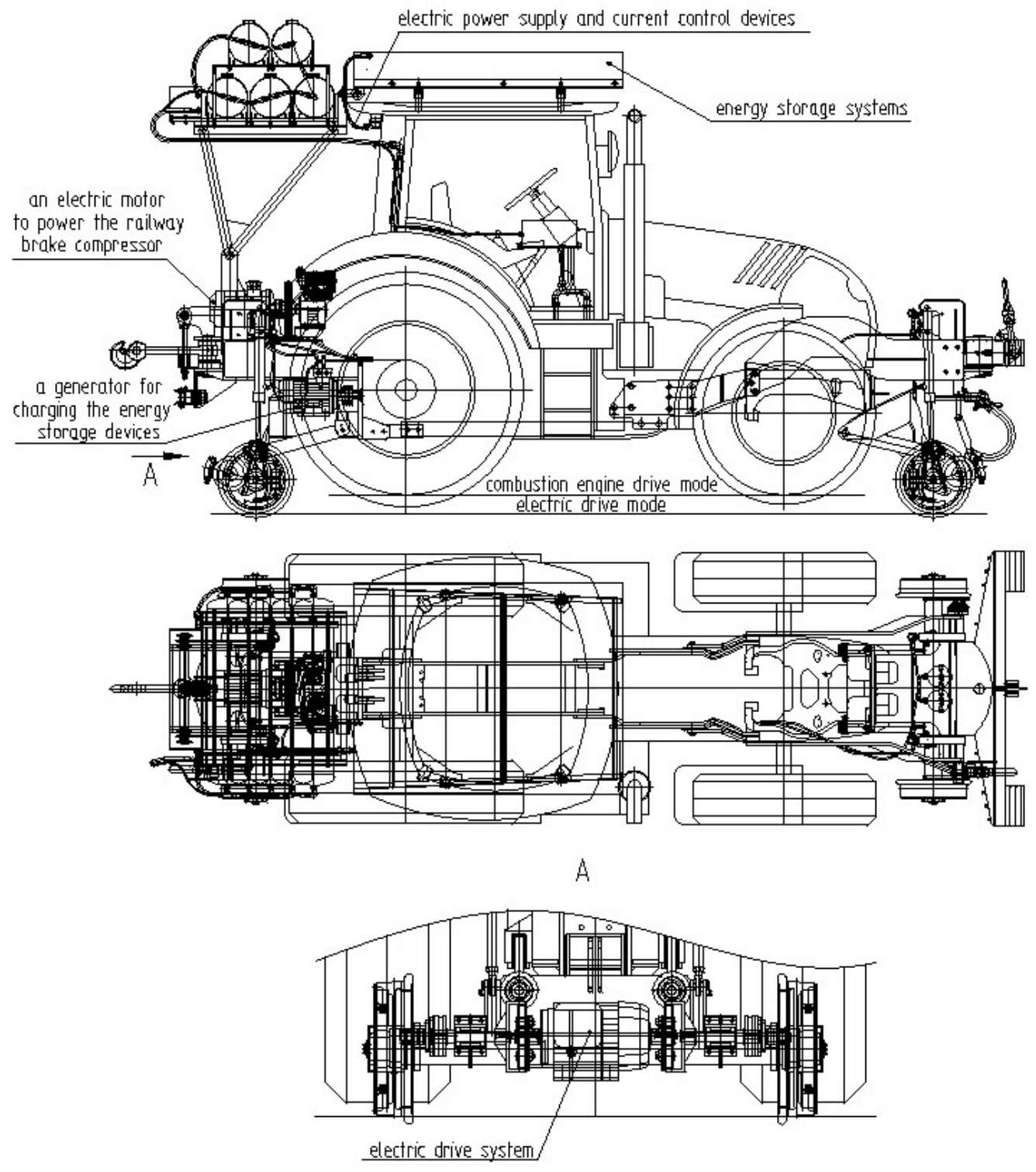

Fig. 2. Schematics of the rail-road tractor with a diesel-electric drive 
The tractor construction design was presented in more detail in [6].

In order to convert the currently manufactured dieselpowered tractor into a diesel-electric tractor, it was equipped with the following additional devices:

- electric drive system for the guide rollers mounted on the rail chassis $\mathbf{1}$

- energy storage systems 2

- the necessary electric power supply and current control devices 3

- a generator for charging the energy storage devices 4

- an electric motor to power the railway brake compressor 5.

In the diesel driving mode, the tractor rests with its tires on the rail heads, driving and braking the tires on the track rails with the natural forces of friction that occur. The coefficient of friction of the tires on the rails as well as the vehicle mass and the power of the internal combustion engine (characteristics shown in Fig. 3) allows for a tractive force of $\sim 55 \mathrm{kN}$ to be achieved on the pull-buffer systems, which enables the rolling of 10 freight wagons with a total weight of 800 tons.

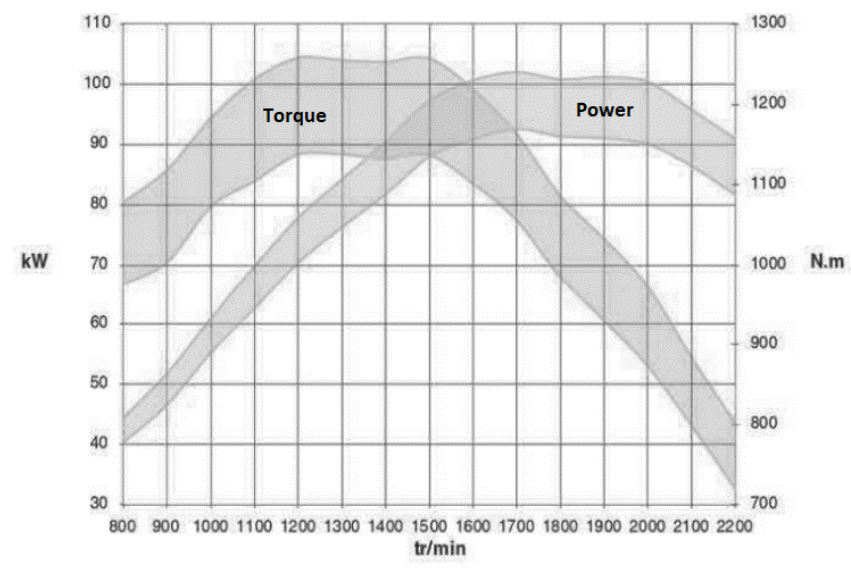

Fig. 3. Characteristics of the combustion engine of the tractor CLAAS Arion 610 [12]

When driving with the use of the electric drive, the tractor is raised by means of hydraulic cylinders to a height where the tires lose contact with the track rails. The entire weight of the tractor rests on the driving rollers of the rail running gear. With a tractor weight of $\sim 10$ tons and a rollerrail friction coefficient of $0.3-0.35$, a tractive force of 30 to $35 \mathrm{kN}$ can be achieved. At this stage of the concept, the traction capabilities of the tractor were not used due to the limited power of the installed electric motors due to their large dimensions.

The assumed technical and operational parameters of the tractor were:

- maximum total weight of the road-rail tractor - 10200 $\mathrm{kg}$,

- the main drive system of the tractor to use on the tracks - internal combustion engine,

- supplementary drive system for driving the tractor on tracks - electric motor,

- powering electric motors - a set of lithium-ion batteries,
- battery charging - external or generator $\sim 3.0 \mathrm{~kW}$,

- maximum tractive force of the conventional drive $-55 \mathrm{kN}$,

- maximum tractive force of the electric drive $-15 \mathrm{kN}$,

- supply voltage of the electric motors $-400 \mathrm{~V}, 50 \mathrm{~Hz}$,

- total power of electric motors $-18.4 \mathrm{~kW}$ (2 motors at $9.2 \mathrm{~kW}$ ),

- energy storage systems capacity - $20 \mathrm{kWh}$,

- weight of the attached rolling stock - max 250 tons,

- maximum working time in electric driving mode $\sim 1.0 \mathrm{~h}$.

\section{The energy storage system}

The diesel-electric hybrid drive is characterized by cyclic recharges and discharges of the battery. The nominal battery charge (SOC) is approximately $50 \%$ (Fig. 4). The use of Ni-MH batteries means that their charge/discharge level is not too high - it is in the range of $40-60 \%$. The use of Li-Ion batteries allows for much higher threshold values: up to $80 \%$ SOC when charging and down to about $20 \%$ when discharged. If the typical range for a battery is 25$75 \%$ SOC, this means that the capacity of the battery used must be twice as large as the intended capacity [1].

Due to the above, it was decided to build a new custom device using the available existing lithium-iron-phosphate (LiFePO4) batteries.

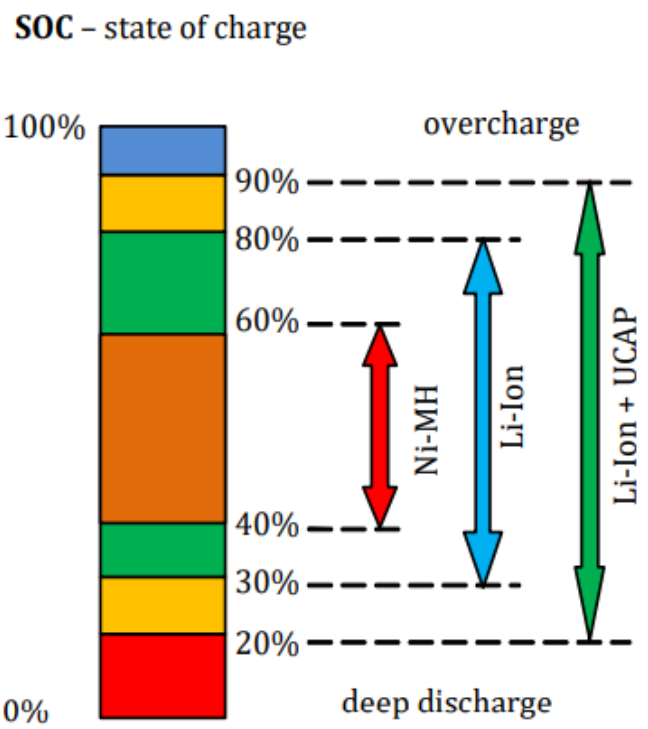

Fig. 4. Conditions for charging and discharging typical battery systems in hybrid drive systems [1]

The energy storage system was placed on the roof of the tractor cab due to the sufficiently large mounting surface of the frame attached to the brackets welded to the cab supporting pillars. The battery system with dimensions of approx. $2000 \times 1600 \times 400 \mathrm{~mm}$ holds 784 batteries with dimensions of $38 \times 146 \mathrm{~mm}$ each (Fig. 5).

Thus a container with the following parameters was obtained:

- total storage capacity $25 \mathrm{kWh}$,

- assumed usable energy of the battery system $\sim 20 \mathrm{kWh}$,

- total mass of the cells $-260 \mathrm{~kg}$,

A single battery and its discharge characteristics were shown in Fig. 6. 

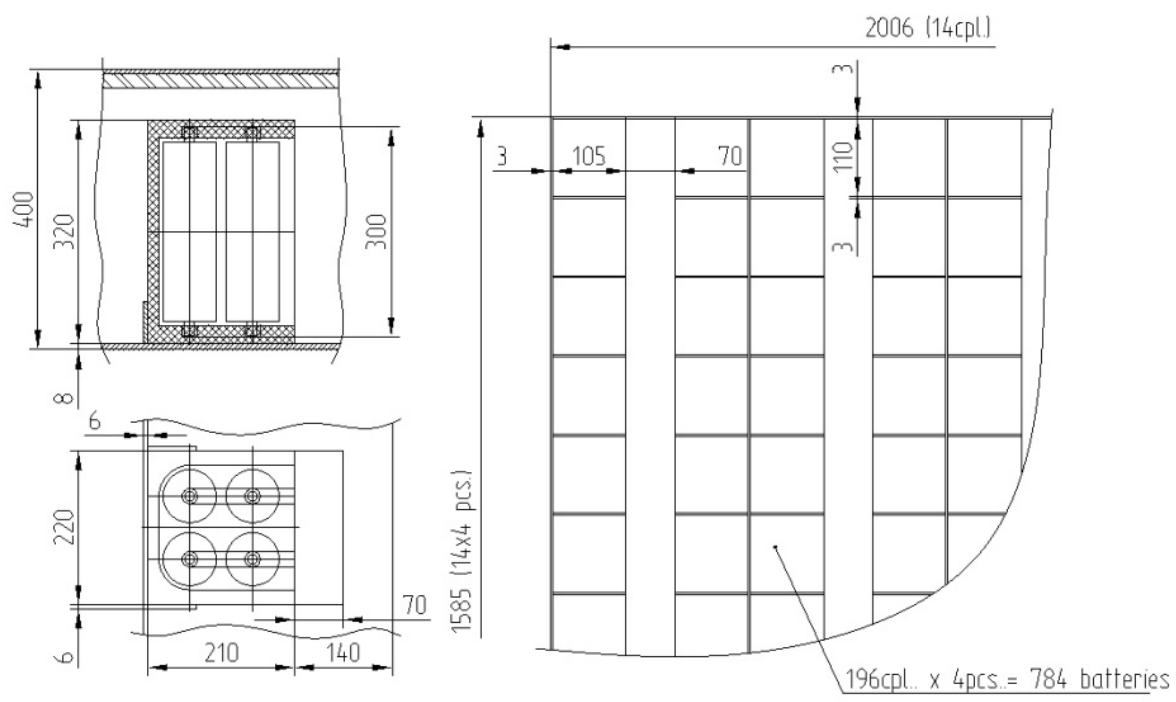

Fig. 5. Energy storage system schematic

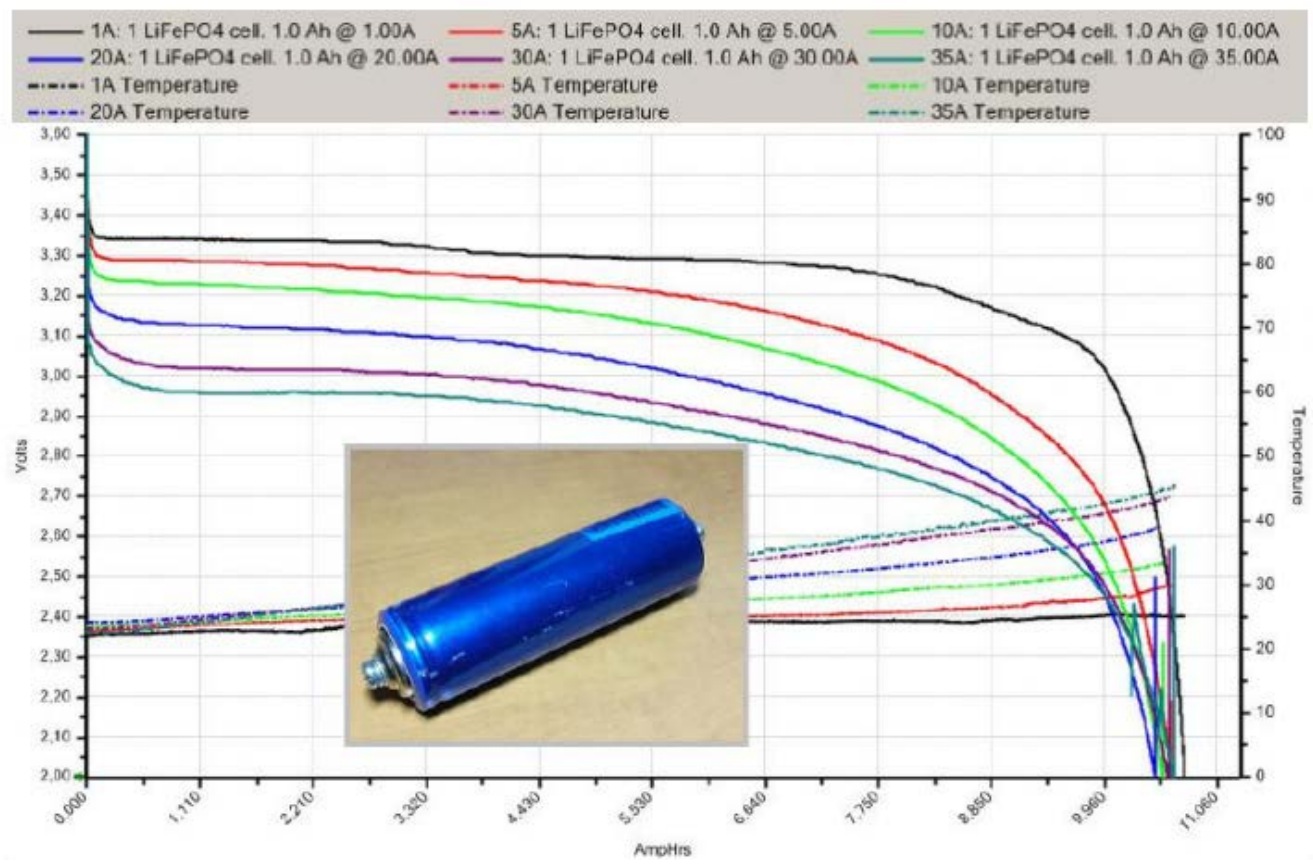

Fig. 6. A single battery cell and its discharge characteristics [11]

Characteristics of a single battery cell:

- voltage $-3.2 \mathrm{~V}$

- capacity - 10 Ah

- internal resistance $<6 \mathrm{~m} \Omega$

- charging voltage $-3.65 \mathrm{~V} \pm 0.05 \mathrm{~V}$

- energy density - $105 \mathrm{Wh} / \mathrm{kg}$

- technology - lithium-iron-phosphate (LiFePO4)

- maximum discharge voltage $-2.5 \mathrm{~V}-2.0 \mathrm{~V}$

- standard charging current - 0.5 C (5 A)

- standard charging time $-2 \mathrm{~h}$

- maximum constant charging current - 2 C (20 A)

- standard discharge current - 1 C (10 A)

- maximum continuous discharge current - 3 C (30 A)

- pulse discharge current - 10 C (100 A)

- operating temperature range:
- charging $0-45^{\circ} \mathrm{C}$

- discharging $-20^{\circ} \mathrm{C}-65^{\circ} \mathrm{C}$

- screw connections - M6 at "+" and "-"

- dimensions - $38 \times 146 \mathrm{~mm}$ (with M6 screws)

- mass - $330 \mathrm{~g}$

- lifespan - over 2000 cycles (80\% of capacity when charging with $1 \mathrm{C}$ current)

- possibility of combining into larger systems Advantages of presented battery cells:

- long lifespan

- no memory effect

- low passive-discharge

- high "peak" power

- high energy density

- high storage capacity with high charge and discharge currents. 


\section{Rail axle assembly}

The vehicle is equipped with two sets of rail axles installed at the front and the rear of the tractor. In diesel driving mode, the role of the rail axles is to guide the vehicle along the track by means of guide rollers mounted at the ends of the axle. The vehicle drives and brakes using the tractor tires resting on the rail heads of the track.

In the electric drive mode, the tractor drives and brakes using the guide rollers coupled with an asynchronous electric motor. An example of a drive solution for the rail axle rollers was shown in Fig. 7.

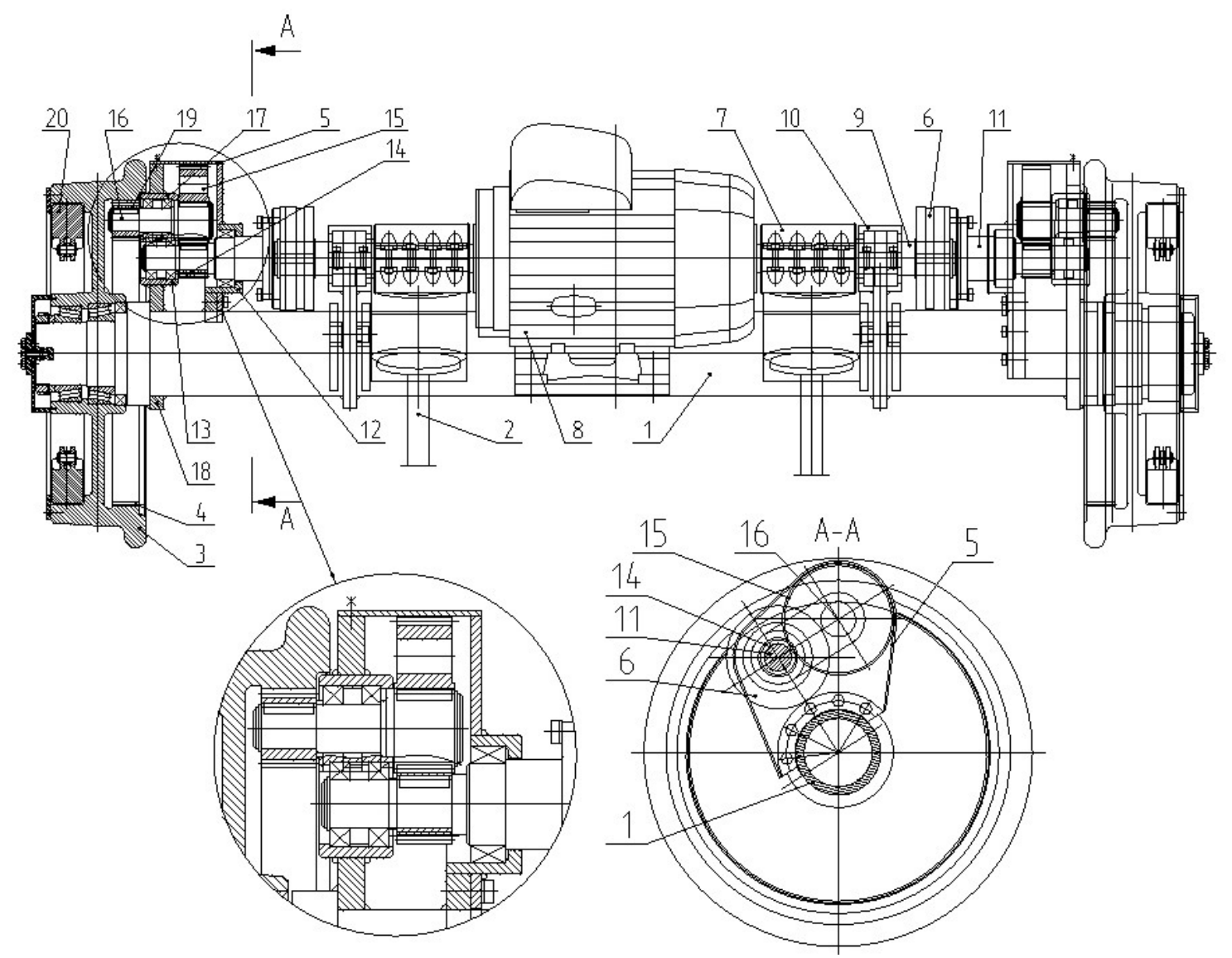

Fig. 7. Rail axle assembly with a double reduction gearbox

The axle assembly consists of the following components:

- axle $\mathbf{1}$ with rocker arms 2

- guide rollers 3 with toothed ring 4

- gear 5

- electromagnetic clutch 6

- split muff coupling 7

- asynchronous motor 8

- brake pad 20.

The asynchronous motor $\mathbf{8}$ is installed in the middle part of the axle $\mathbf{1}$. The motor has a drive shaft that extends to both sides of the motor. The shaft $\mathbf{9}$ of one part of the electromagnetic clutch $\mathbf{6}$ is connected to the drive shaft of the motor by a split muff coupling 7 . The shaft $\mathbf{9}$ is mounted in the housing $\mathbf{1 0}$ attached to the axle $\mathbf{1}$. The other part of the clutch $\mathbf{6}$ is mounted on the shaft 11, mounted in the sleeves 12 and 13. The shaft $\mathbf{1 1}$ has a small toothed wheel $\mathbf{1 4}$ connected with the larger toothed wheel $\mathbf{1 5}$, which is attached to the shaft $\mathbf{1 6}$ mounted on a bearing in the housing $\mathbf{1 7}$ welded to the bracket $\mathbf{1 8}$, which is then mounted on the axle 1. At the other end of the shaft $\mathbf{1 6}$ there is a small toothed wheel 19, which cooperates with the toothed ring 4 made in the guide roller 3 .

The gear ratio between guide rollers 3 and the toothed wheel $\mathbf{1 9}$ is 8.6. The gear ratio of the gear $\mathbf{5}$ is 3.1. The overall ratio between the revolutions of the motor and the revolutions of the guide rollers is $26.66 \approx 27$.

The previously developed solutions of the rail axle roller drive concept [6] were limited to the use of one toothed gear with a gear ratio of 8.6. In this case, at the nominal motor speed of $1420 \mathrm{rpm}$, the vehicle would be moving at a speed of $\sim 15 \mathrm{~km} / \mathrm{h}$. In shunting traffic, the speed of 3-5 $\mathrm{km} / \mathrm{h}$ is safe. Thus, an additional toothed transmission was used to reduce the theoretical speed of the vehicle to $\sim 5$ $\mathrm{km} / \mathrm{h}$. When designing the additional gear $\mathbf{5}$, it was assumed that the gear housing would fit within the outer contour of the guide roller. The consequence of this assumption is the necessity to make an appropriate depression or bend of the axle $\mathbf{1}$ at the point of motor mounting to the axle $\mathbf{1}$. The drive solution shown in Fig. 8 does not have this disadvantage. 


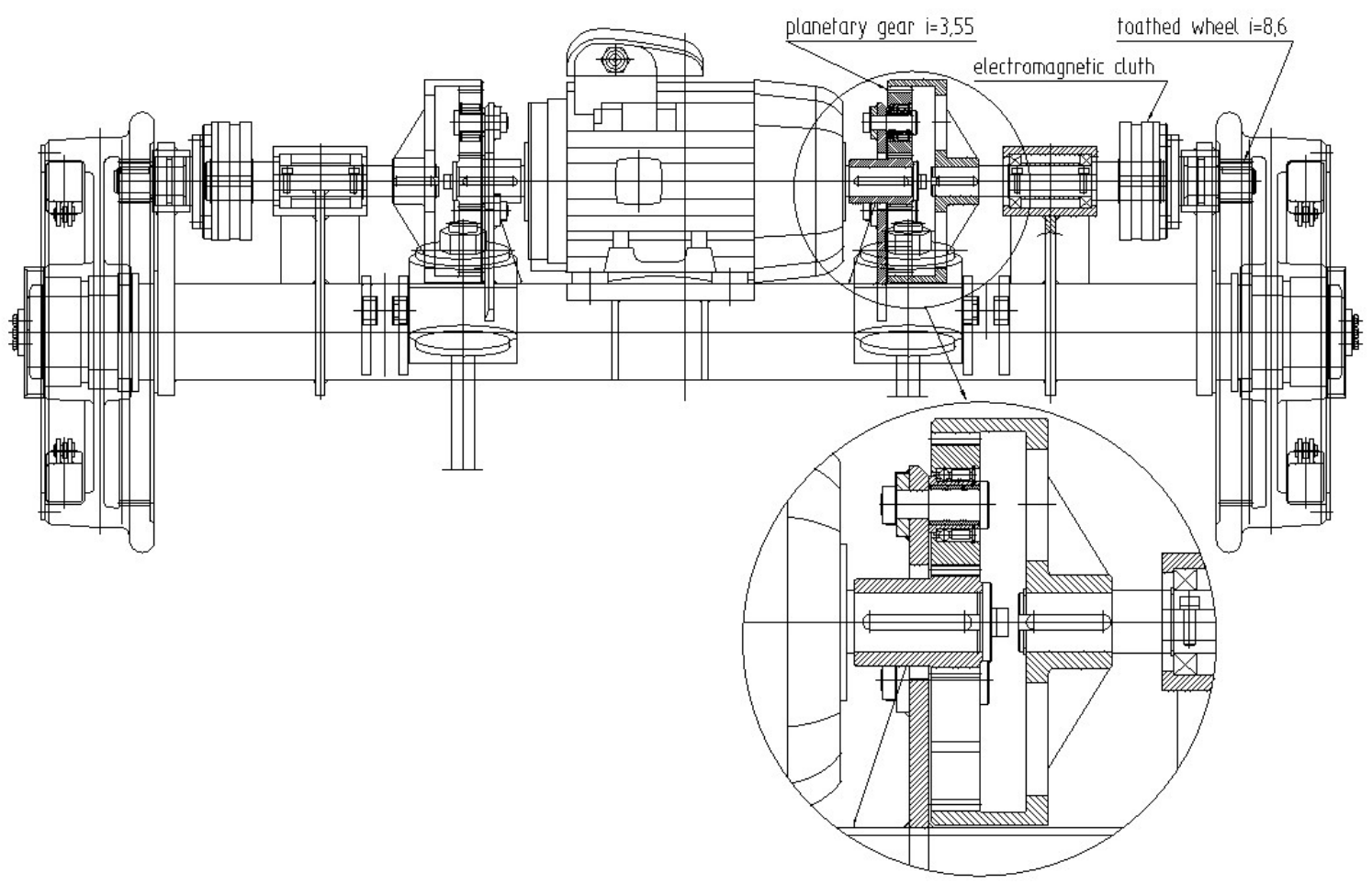

Fig. 8. Rail axle assembly with a planetary gear

Figure 8 provides an alternative solution using a planetary gear. In this guide roller drive concept, the drive shafts were arranged in one axis, which significantly simplifies the design of the drive system. A gear ratio of 3.55 was obtained in the planetary gear. The limitation of increasing the gear ratio is the distance of the shaft axis from the outer contour of the rail axle.

The electric motor used in the project was an asynchronous, three-phase motor with a double-sided shaft, type DELPHI 132MB-4-(IMB3) from the Italian company MOTIVE S.r.l (Fig. 9).

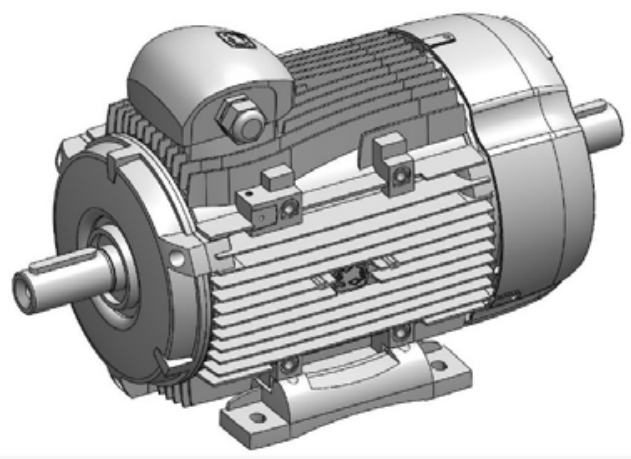

Fig. 9. DELPHI 132 MB-4-(IMB3) electric motor [13]

The technical parameters of the motor are as follows:

- motor power - $9.2 \mathrm{~kW}$

- nominal motor speed - $1420 \mathrm{rpm}$

- torque at nominal rpm - 61.6 Nm

- number of poles - 4

- motor mass - $55 \mathrm{~kg}$

- guide rollers torque:

$$
\mathrm{M}_{\mathrm{K}}=61.6 \cdot 30.55=1880 \frac{\mathrm{Nm}}{\mathrm{axle}}
$$

- roller speed:

$$
\mathrm{n}_{\mathrm{K}}=\frac{1420}{30.55}=46.5 \mathrm{rpm}
$$

- roller rotational speed:

$$
\omega_{\mathrm{K}}=\frac{\mathrm{n}_{\mathrm{K}}}{60} \cdot 2 \pi=4.9 \frac{\mathrm{rad}}{\mathrm{s}}
$$

- roller linear speed

$$
\begin{aligned}
\mathrm{V}_{\mathrm{K}} & =\mathrm{R}_{\mathrm{K}} \cdot \omega_{\mathrm{K}}=0.25 \mathrm{~m} \cdot 4.9 \frac{\mathrm{rad}}{\mathrm{s}}= \\
& =1.22 \frac{\mathrm{m}}{\mathrm{s}} \cdot 3.6=4.3 \frac{\mathrm{km}}{\mathrm{h}}
\end{aligned}
$$

- torque on the rollers of one rail axle:

$$
\mathrm{F}_{\mathrm{K}}=\frac{\mathrm{M}_{\mathrm{K}}}{\mathrm{R}_{\mathrm{K}}}=\frac{1880 \mathrm{Nm}}{0,25 \mathrm{~m}}=7520 \mathrm{~N} \approx 7.5 \frac{\mathrm{kN}}{\text { axle }}
$$

- tractor pulling force:

$$
\mathrm{F}_{\mathrm{c}}=7.5 \cdot 2 \approx 15 \mathrm{kN}
$$

In the analyzed example, the planetary gear ratio $\mathrm{i}=3.55$ was used. By increasing the gear ratio, e.g. to $\mathrm{i}=4$ the tractive force can be increased to a value of $\mathrm{F} \approx 20 \mathrm{kN}$.

\section{Conclusions}

The results of analyzes of the energy storage system selection and two concepts of the guide roller assemblies of the rail drive system were presented.

The surface of the tractor cab roof and the strength of the load-bearing pillars allows for mounting one layer of the energy storage system weighing $\sim 260 \mathrm{~kg}$ with a battery 
capacity $\sim 20 \mathrm{kWh}$. The obtained energy capacity of the storage system allows for continuous operation in electric driving mode for 1-1.5 hour. It is possible to install additional energy storage units of smaller dimensions, e.g. on the front supporting structure of the pull-buffer system. This makes it reasonably possible to increase the energy capacity of the tractor battery system.

Two drive system concepts for the tractor rail axle guide rollers were presented. A drive system with a planetary gear was selected for further analysis, with a proposal to increase the gear ratio to $\mathrm{i} \approx 4$ in order to obtain a higher torque on the guide rollers.

The conducted analyzes used standard, cheap, lowspeed asynchronous motors available on the market with a power of $9.2 \mathrm{~kW}$, which allow obtaining a tractive force of $\sim 15 \mathrm{kN}$.

In order to use the full traction capabilities of the tractor in the driving mode using the electric drive $(\sim 30 \mathrm{kN}$ of tractive force), it was necessary to search for an motor with greater rated power, which would achieve more than a twofold increase in torque on the rail axle guide rollers. In Poland, research is being carried out on the design of specialized motors for use in electric vehicle drives. The experience of manufacturing companies should be fully leveraged by establishing cooperation in further research works, such as between Łukasiewicz - KOMEL.

The design solution used in the preliminary project draft was submitted for patent protection.

\section{Nomenclature}

$\begin{array}{llll}\mathrm{F} & \text { force } & \mathrm{V} & \text { linear speed } \\ \mathrm{M} & \text { turque } & \omega & \text { rotational speed }\end{array}$

n speed

\section{Bibliography}

[1] ANDRZEJEWSKI, M., PIELECHA, I., MERKISZ, J. et al. Modern drive systems of rail vehicles. Combustion Engines. 2019, 178(3), 76-81. https://doi.org/10.19206/CE-2019-314.

[2] BIAŁAS, A., ROSSA, R. Napęd elektryczny E-KIT dla miejskiego samochodu osobowego. Napędy $i$ sterowanie. 2014, 9.

[3] BRYK, K., ŁUKASZEWSKI, K., MEDWID, M. Symulacyjne badania bezpieczeństwa ruchu ciągnika szynowo-drogowego CLAAS ARION 620. Międzynarodowa Konferencja Naukowa TRANSPORT XXI WIEKU. Arłamów 2016.

[4] DĄBALA, K., DUDZIŃSKI, J. Napęd bezpośredni w pojazdach samochodowych - przegląd konstrukcji. Praca Instytutu Elektrotechniki. 2012, 260.

[5] MEDWID, M. Hybrydowe pojazdy kolejowo-drogowe zaprojektowane i wytwarzane w Polsce. Technika Transportu Szynowego. 2005, 7-8.

[6] MEDWID, M., DASZKIEWICZ, P., CZERWIŃSKI, J. et al. Rail-road tractor with diesel-electric drive. Rail Vehicles. 2019, 3.

Sylwin Tomaszewski, DEng. - Łukasiewicz Research Network - Rail Vehicles Institute "TABOR" in Poznan..

e-mail: sylwin.tomaszewski@tabor.lukasiewicz.gov.pl

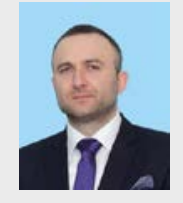

Maciej Andrzejewski, DEng. - Łukasiewicz Research Network - Rail Vehicles Institute "TABOR" in Poznan.

e-mail: maciej.andrzejewski@tabor.lukasiewicz.gov.pl
[7] MEDWID, M., JAKUSZKO, W., KAZIMIERCZAK, E. Structural features of the tractor selected for adaptation to the new road-rail vehicle. Rail Vehicles. 2017, 3.

[8] MEDWID, M., STAWECKI, W., CZERWIŃSKI, J. et al. Structure modeling of the CLAAS ARION 620 road-rail shunting tractor. Rail Vehicles. 2017, 2.

[9] MEDWID, M., STAWECKI, W., CZERWIŃSKI, J. et al. Multi-purpose rail-road tractor of the new generation. Rail Vehicles. 2016, 3.

[10] SINGH, K.V., BANSAL, H.O., SINGH, D. A comprehensive review on hybrid electric vehicles: architectures and components. Journal of Modern Transportation. 2019, 27, 77-107. https://doi.org/10.1007/s40534-019-0184-3

[11] Battery Trade Office. https://bto.pl access date: 2020-08-21.

[12] CLAAS. https://claas.pl access date: 2020-08-17.

[13] MOTIVE SLR. https://motive.it access date: 2020-08-25.

Prof. Marian Medwid, DSc., DEng. - Łukasiewicz Research Network - Rail Vehicles Institute "TABOR” in Poznan.

e-mail: marian.medwid@tabor.lukasiewicz.gov.pl
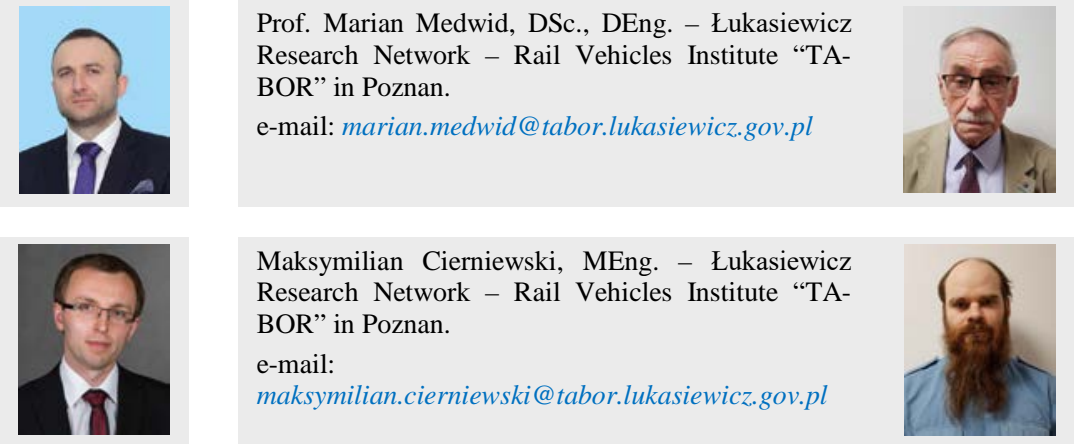

Maksymilian Cierniewski, MEng. - Łukasiewicz Research Network - Rail Vehicles Institute "TABOR” in Poznan.

e-mail:

maksymilian.cierniewski@tabor.lukasiewicz.gov.pl

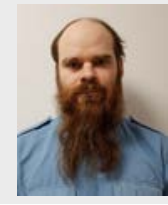

Wojciech Jakuszko, MEng. - Łukasiewicz Research Network - Rail Vehicles Institute “TABOR” in Poznan.

e-mail:wojciech.jakuszko@tabor.lukasiewicz.gov.pl

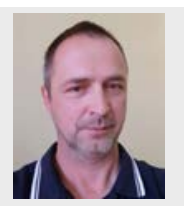

